\title{
Heat Shock Induces Resistance in Rat Pancreatic Islet Cells against Nitric Oxide, Oxygen Radicals and Streptozotocin Toxicity In Vitro
}

\author{
Kerstin Bellmann, Andrea Wenz, Jürgen Radons, Volker Burkart, Rainer Kleemann, and Hubert Kolb \\ Diabetes Research Institute at the Universität of Düsseldorf, Auf'm Hennekamp 65, D-40225 Düsseldorf, Germany
}

\begin{abstract}
When cultures of pancreatic islet cells are exposed to the nitric oxide donor sodium nitroprusside, to enzymatically generated reactive oxygen intermediates or to streptozotocin cell lysis occurs after 4-12 h. We report here that a heat shock at $43^{\circ} \mathrm{C}$ for 90 min reduces cell lysis from nitric oxide ( $0.45 \mathrm{mM}$ sodium nitroprusside) by $70 \%$, from reactive oxygen intermediates (12 $\mathrm{mU}$ xanthine oxidase and $0.05 \mathrm{mM}$ hypoxanthine) by $80 \%$ and from streptozotocin (1.5 mM) by $90 \%$. Heat shock induced resistance was observed immediately after termination of the 90 min culture at $43^{\circ} \mathrm{C}$ and correlated with enhanced expression of hsp70. The occurrence of DNA strand breaks, a major early consequence of nitric oxide, reactive oxygen intermediates, or streptozotocin action, was not suppressed by heat shock treatment. However, the depletion of $\mathrm{NAD}^{+}$, the major cause of radical induced islet cell death, was suppressed after heat shock $(P$ $<0.01$ ). We conclude that pancreatic islet cells can rapidly activate defence mechanisms against nitric oxide, reactive oxygen intermediates and streptozotocin by culture at $43^{\circ} \mathrm{C}$. Islet cell survival is due to the prevention of lethal NAD ${ }^{+}$ depletion during DNA repair, probably by slowing down poly (ADP-ribose) polymerase activation. (J. Clin. Invest. 1995. 95:2840-2845.) Key words: sodium nitroprusside • xanthine oxidase $\cdot$ DNA strand breaks $\bullet$ pancreatic islet cells - NAD ${ }^{+}$level
\end{abstract}

\section{Introduction}

Nitric oxide (NO) ${ }^{1}$ and reactive oxygen intermediates (ROI) are assumed to be major mediators of beta cell death during prediabetic islet inflammation $(1,2)$. The toxic action of proinflammatory cytokines such as interleukin 1 (IL-1) on islet cell function also appears to be mediated in part by NO and ROI $(3,4)$. IL-1-induced islet cell death could be completely inhibited by blocking NO formation. Isolated islet cells have been

Address correspondence to Dr. H. Kolb, Diabetes Research Institute, Clinical Department, Heinrich-Heine University, Auf'm Hennekamp 65, D-40225 Düsseldorf, Germany. Phone: 211-3382-643; FAX: 211 3382-606.

Received for publication 23 August 1994 and in revised form 29 December 1994.

1. Abbreviations used in this paper: hsp, heat shock protein; NO, nitric oxide; PARP, poly (ADP-ribose)polymerase; ROI, reactive oxygen intermediates; SZ, streptozotocin.

J. Clin. Invest.

(c) The American Society for Clinical Investigation, Inc. 0021-9738/95/06/2840/06 \$2.00

Volume 95, June 1995, 2840-2845 found highly susceptible to the toxic effects of ROI and NO $(5,6)$. This may be due to a low radical scavenging potential and $\mathrm{NAD}^{+}$content (7).

A model of chemically induced islet cell death in vivo and in vitro is the streptozotocin (SZ) mediated islet cell destruction $(8,9) . \mathrm{SZ}$ is an alkylating agent that causes DNA strand breaks in rat pancreatic islet cells (10). Recent results strengthen the hypothesis that the toxic effects of SZ are in part mediated by NO which is generated during its metabolization (Kröncke, K. D., K. Fehsel, M.-L. Rodriguez, and V. Kolb-Bachofen, manuscript submitted for publication) (11).

The two inflammatory products $\mathrm{NO}$ and ROI as well as SZ share the ability to induce DNA strand breaks, to activate poly (ADP-ribose)polymerase (PARP) and to deplete NAD $^{+}$ $(12,13)$. Recent studies with islet cells lacking an intact PARP gene confirm this model of cell death but show also the existence of an alternative PARP/NAD ${ }^{+}$independent mechanism of NO and ROI toxicity (14).

Little is known about defense mechanisms of islet cells against cytotoxic agents. Earlier studies showed that high glucose levels improve the resistance against ROI and SZ (5) but not against NO (15). Recent studies indicate a cytoprotective role of heat shock proteins (hsps) against a variety of toxic mediators. Fusion of islet cells with hsp70 containing liposomes transiently suppressed toxic effects of IL-1 (16). By overexpressing hsp70 a human tumor cell line became resistant to the cytotoxic effects of TNF $\alpha$ and hydrogen peroxide (17). In mammalian cells the hsp70 family is the most conserved heat shock protein family (18). Increased expression of heat shock proteins is seen after stressing cells with elevated temperatures or after exposure to ethanol, arsenite, cadmium chloride and viral infections. Furthermore it was shown that IL-1 induces stress proteins in rat pancreatic islets such as hsp70, hsp90 and heme oxygenase (19). A common effect of many stress protein inducers is a change in the oxidative state of the cell and an accumulation of abnormal or denatured proteins (20).

In the present paper we analyzed whether a stress response induced in islet cells by heat shock would affect the defense against inflammatory mediators or the model toxin SZ.

\section{Methods}

Islet cell preparation. Pancreatic islet cells were prepared from male and female outbred Wistar rats, 80-120 d old (provided from the central animal facilities, University of Düsseldorf). Islet cells were isolated by injection of a collagenase solution in the pancreatic duct $(0.37 \mathrm{U} / \mathrm{mg}$; Serva GmbH, Heidelberg, FRG) in Hank's balanced salt solution (HBSS; GIBCO BRL, Eggenstein, FRG). After digestion for $40 \mathrm{~min}$ at $37^{\circ} \mathrm{C}$ the pancreatic tissue was dispersed, and the islets were enriched by centrifugation on a Ficoll density gradient (Ficoll 400; Pharmacia $\mathrm{GmbH}$, Freiburg, FRG) and by subsequent handpicking. The islets were dissociated into single cells in the presence of trypsin in $\mathrm{Ca}^{2+}$ - and $\mathrm{Mg}^{2+}$-free HBSS. For the in vitro assays the cells were incubated $\left(37^{\circ} \mathrm{C}\right.$, $5 \% \mathrm{CO}_{2}$ ) in RPMI 1640 (GIBCO BRL) with $4.5 \mathrm{mM}$ glucose, supple- 
mented with ampicillin $25 \mathrm{mg} /$ liter, penicillin $120 \mathrm{mg} /$ liter, streptomycin $270 \mathrm{mg} /$ liter (Serva), sodium pyruvate $1 \mathrm{mM}$, L-glutamine $2 \mathrm{mM}$, nonessential amino acids $(100 \times) 10 \mathrm{ml} / \mathrm{liter}(\mathrm{GIBCO} \mathrm{BRL}), \mathrm{NaHCO}_{3}$ 2 grams/liter, Hepes 2.38 grams/liter, $\mathrm{pH} 7.3$, (Serva) and 10\% fetal calf serum (FCS; GIBCO BRL).

Heat shock treatment. Islet cells were seeded in flat bottom microtiter plates at $2 \times 10^{4}$ cells $/ 120 \mu \mathrm{l}$ per well. The cells were exposed to $43^{\circ} \mathrm{C}$ for $90 \mathrm{~min}(21)$. For some experiments the heat shock temperature and time were varied as indicated in the text.

Cytotoxicity assay. ROI were generated during the oxidation of hypoxanthine (HX; Sigma Chemical Co., St. Louis, MO) by xanthine oxidase (XO, Sigma Chemical Co.) (22). Nitric oxide was generated by the decomposition of sodium nitroprusside (NP; Merck, Darmstadt, FRG) in the presence of $8 \mathrm{U} / 120 \mu \mathrm{l}$ thodanese (Sigma Chemical Co.) and $5 \mathrm{mM} \mathrm{Na}_{2} \mathrm{~S}_{2} \mathrm{O}_{3}$ in order to inactivate cyanide ions (23). Streptozotocin (SZ, Boehringer Mannheim FRG) was dissolved freshly in culture medium before use. Heat shock or sham treated islet cells $\left(2 \times 10^{4} /\right.$ well) were exposed to ROI, NO or SZ for $16 \mathrm{~h}$. The cell viability was determined by the Trypan blue exclusion assay. At least 200 islet cells were evaluated microscopically per well. All tests were done in triplicate. Specific islet cell lysis was calculated according to the following formula:

specific lysis $(\%)=100 \times \frac{\text { lysis in test }- \text { spontaneous lysis }}{\text { maximal lysis }- \text { spontaneous lysis }}$

Maximal lysis was defined as $100 \%$ of Trypan blue-stained cells. Spontaneous lysis of untreated control cells was in a range of $10 \pm 3 \%$, lysis of heat treated control cells was in a range of $15 \pm 3 \%$.

Intracellular $\mathrm{NAD}^{+}$content. Islet cell $\mathrm{NAD}^{+}$content was measured by an enzymatic cycling method using alcohol dehydrogenase from $\mathrm{S}$. cerevisiae (Boehringer Mannheim) as previously described $(24,25)$.

Western blot. Islet single cells were seeded in 12-well plates at 5 $\times 10^{5}$ cells $/ 2 \mathrm{ml}$ per well. Cells were washed twice with ice-cold PBS, lysed in Laemmli sample buffer (26) and boiled for $5 \mathrm{~min}$. Lysates were electrophoresed in 10\% SDS-PAGE (25) and blotted on a Hybond ECL-Western nitrocellulose membrane (Amersham, Braunschweig, FRG). Filters were blocked for $30 \mathrm{~min}$ with TBS containing 5\% dry milk and incubated with a mouse monoclonal antibody directed against the inducible form of heat shock protein 70 (hsp70) (C92F3A-5; Stress Gene, Victoria, B.C., Canada) and with a rat monoclonal antibody specific for the constitutive form of hsp70 (hsc70) (1B5; Stress Gene) both diluted 1:1,000 for $1 \mathrm{~h}$. After washing in TBS containing $0.06 \%$ Tween 20 (Sigma Chemical Co.) the filters were incubated for $30 \mathrm{~min}$ with a peroxidase labeled anti-mouse antibody diluted 1:50,000 (Amersham) followed by a detection step with the ECL-detection reagent (Amersham). Air-dried filters were exposed to Hyperfilm-ECL (Amersham).

Immunocytochemistry and in situ nick translation. Islet cells were seeded on collagen coated (Sigma Chemical Co.) chamber slides (Nunc, Naperville, IL) at $2 \times 10^{4}$ per well. The cells were air dried and fixed in methanol $\left(-20^{\circ} \mathrm{C}\right)$ for $2 \mathrm{~min}$. The cells were incubated with the hsp70 antibody (Stress Gene) for $16 \mathrm{~h}$ at $4^{\circ} \mathrm{C}$. After washing in PBS the cells were incubated with a biotinylated horse anti-mouse IgG $(\mathrm{H}$ $+\mathrm{L}$ ) antibody (Vector, Burlingame, CA) for $30 \mathrm{~min}$ at room temperature followed by a detection step with avidin-biotin-peroxidase (Vectastain kit; Camon, Wiesbaden, FRG) using diaminobenzidine as substrate.

For the detection of DNA strand breaks in individual cell nuclei cells were analyzed by in situ nick translation (27). Islet cells $\left(2 \times 10^{4} /\right.$ well) were seeded on collagen-coated chamber slides (Nunc). The cells were fixed in acetone $\left(4^{\circ} \mathrm{C}\right)$ for $10 \mathrm{~min}$ and for $30 \mathrm{~min}$ in methanol containing $0.3 \% \mathrm{H}_{2} \mathrm{O}_{2}$. The nick translation mixture was composed of $3 \mu \mathrm{M}$ biotin-dUTP; $4 \mathrm{U} / 100 \mu \mathrm{l}$ Kornberg polymerase; $3 \mu \mathrm{M}$ each dGTP, dCTP, dATP; $50 \mathrm{mM}$ Tris- $\mathrm{HCl}$, pH 7.5; $5 \mathrm{mM} \mathrm{MgCl}$; 0.1 $\mathrm{mM}$ dithiothreitol (all components from Boehringer Mannheim). The reaction was performed for $15 \mathrm{~min}$ at room temperature. After washing in PBS the cells were dehydrated in ethanol $(30,50,70,80$, and $90 \%$; 1 min each). Biotin-dUTP was visualized with streptavidin-biotin-peroxidase (Vector) using diaminobenzidine as substrate. The percentage

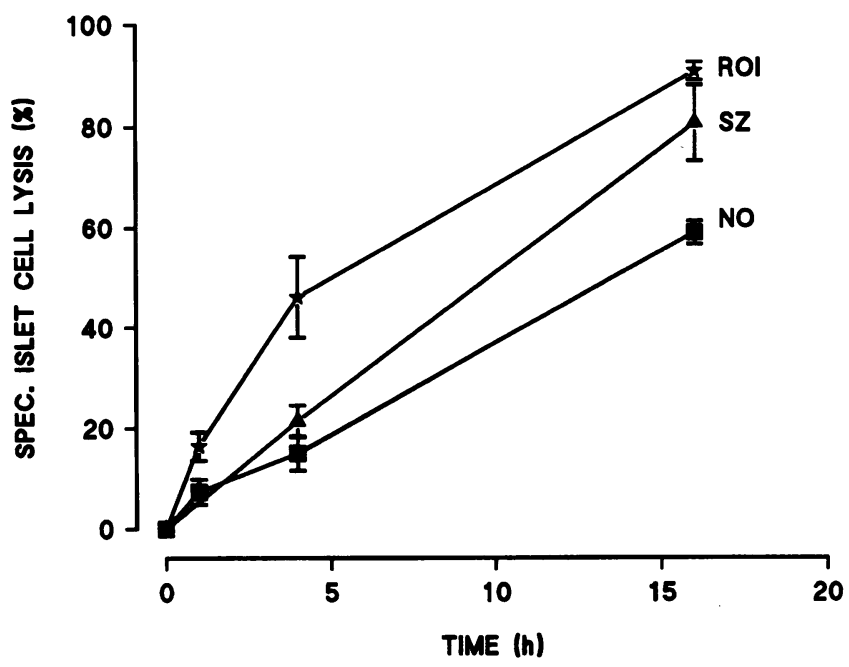

Figure 1. Time course of islet cell lysis. Islet cells were exposed to NO ( $0.45 \mathrm{mM}$ sodium nitroprusside), ROI ( $12 \mathrm{mU}$ xanthine oxidase, 0.05 $\mathrm{mM}$ hypoxanthine) or to streptozotocin $(1.0 \mathrm{mM})$. After different time intervals the cell lysis was determined. Data represent means \pm SD of at least six tests.

of stained nuclei was determined microscopically in at least 200 cells per well.

Assay for poly(ADP-ribose) polymerase. PARP activity was determined following the method of Grube et al. (28). Islet cells $\left(1.25 \times 10^{5}\right)$ were washed in PBS and resuspended in $66 \mu$ ice-cold permeabilization buffer ( $10 \mathrm{mM}$ Tris, pH 7.8, $1 \mathrm{mM}$ EDTA, $4 \mathrm{mM} \mathrm{MgCl}_{2}, 30 \mathrm{mM} \beta$ mercaptoethanol). The cells were kept on ice for $15 \mathrm{~min}$. Microscopic examination revealed that $>95 \%$ of the cells were permeabilized. To each sample was added $34 \mu \mathrm{l}$ of $3 \times$ reaction buffer $(100 \mathrm{mM}$ Tris, $\mathrm{pH}$ 7.8, $\left.120 \mathrm{mM} \mathrm{MgCl}_{2}\right)$ containing $0.5 \mu \mathrm{Ci}$ [adenine- $2,8-{ }^{3} \mathrm{H}$ ] NAD ${ }^{+}(23$ $\mathrm{Ci} / \mathrm{mmol}$; ICN Biomedicals, Irvine, $\mathrm{CA}$ ). The reaction was carried out at $30^{\circ} \mathrm{C}$ for $30 \mathrm{~min}$ and stopped by adding $1 \mathrm{ml}$ of $10 \%$ TCA, $2 \%$ sodiumpyrophosphate. After $2 \mathrm{~h}$ of incubation on ice precipitates were collected on glass fiber filter plates (Millipore, Eschborn, FRG) and washed with $3 \times 300 \mu \mathrm{l} 10 \%$ TCA, $2 \%$ sodiumpyrophosphate and 2 $\times 300 \mu 196 \%$ ethanol. After drying and liquid scintillation counting was carried out in Ultima Gold (Packard Instrument, Groningen, Netherlands) in a $\beta$-counter (Beckmann Instruments, Fullerton, CA).

Statistical analysis. Statistical analysis was performed using the Student's t test, two sided.

\section{Results}

Kinetics of islet cell death. To investigate the kinetics of cell lysis islet cells from normal Wistar rats were exposed for various time intervals to the NO donor sodium nitroprusside (NP), to ROI generated by the enzyme xanthine oxidase or to the $\beta$ cell toxin streptozotocin (SZ). As shown in Fig. 1 cell lysis starts to occur after a few hours of exposure to the toxic agents and $60-90 \%$ lysis is reached after $16 \mathrm{~h}$ of culture.

Protection from lysis by heat shock. To study whether heat shock treatment induces resistance in pancreatic islet cells against the cytotoxicity of SZ, ROI, or NO, a modification of the in vitro model of islet cell death was used. Isolated islet cells were exposed to a heat shock treatment at $43^{\circ} \mathrm{C}$ for 90 min. After a recovery period of $30 \mathrm{~min}$ at $37^{\circ} \mathrm{C}$ the cells were exposed to SZ, ROI, or NO and the cell lysis was determined after $16 \mathrm{~h}$. Heat shock reduced the specific lysis mediated by 


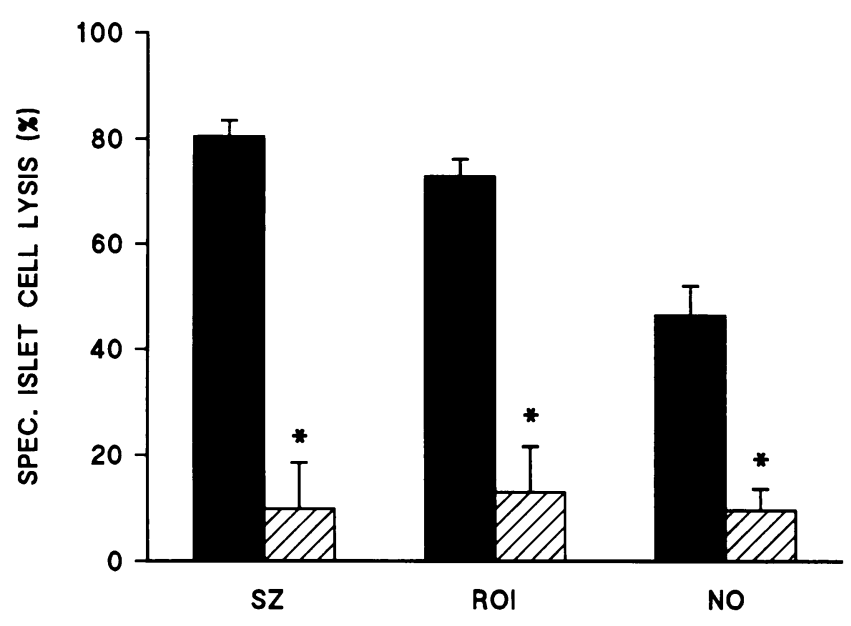

Figure 2. Heat shock protects against islet cell lysis. Islet cells were exposed to $\mathrm{SZ}$ ( $1.5 \mathrm{mM}$ ), ROI ( $12 \mathrm{mU}$ xanthine oxidase, $0.05 \mathrm{mM}$ hypoxanthine $)$, or NO ( $0.45 \mathrm{mM}$ sodium nitroprusside $)$ for $16 \mathrm{~h}$. Solid bars indicate the sham-treated cells; hatched bars indicate the cells heat shocked at $43^{\circ} \mathrm{C}$ for $90 \mathrm{~min}$. Data represent means \pm SD of at least six tests.

SZ from 80 to $10 \%$, the ROI induced lysis was reduced from 73 to $13 \%$ and the NO induced lysis from 46 to $10 \%$ (Fig. 2).

Expression of hsp70. To test whether the heat shock treatment induces hsp70 the pancreatic islet cells were stained with an antibody directed against the inducible form of hsp70. Untreated control cells showed a weak background staining (Fig. $3 \mathrm{~A}$ ) whereas cells exposed to a heat shock at $43^{\circ} \mathrm{C}$ for 90 min showed intensive staining (Fig. $3 \mathrm{~B}$ ). Similar results were obtained with antibodies directed against hsp60 and hsp65 (data not shown). Western blot analysis revealed enhanced hsp70 expression after heat shock, whereas hsc70 is not induced by heat shock but is expressed constitutively also under non heat shock conditions (Fig. $3 \mathrm{C}$ ).

Kinetics of heat shock response. To study the kinetics of the heat shock response the recovery period between heat shock and addition of SZ was varied between 0 and $120 \mathrm{~min}$. As shown in Fig. $4 \mathrm{~A}$ the stress induced islet cell resistance was seen immediately after the $90 \mathrm{~min}$ heat shock period and did not further improve by subsequent culture at $37^{\circ} \mathrm{C}$ for up to 120 min. Variation of duration and temperature of the heat shock treatment (Fig. $4 B$ ) revealed that islet cell protection against $\mathrm{SZ}$ can be seen already at lower temperature of heat shock $\left(42^{\circ} \mathrm{C}, 30 \mathrm{~min}\right.$ ) but that the optimum is reached at $43^{\circ} \mathrm{C}$ for 90 min. Higher temperature or longer incubation periods resulted in increased spontaneous lysis of islet cells (data not shown).

Mechanism of protection. Since DNA strand breaks are crucial events in NO, ROI, and SZ toxicity we determined whether heat shock treatment had prevented ROI induced DNA damage. Analysis of cells by in situ nick translation showed no effect of heat shock treatment on the kinetics and incidence of cell nuclei with detectable DNA damage (Fig. 5).

Next we analyzed whether the depletion of intracellular $\mathrm{NAD}^{+}$, which occurs in islet cells in response to DNA damage, would be affected by heat shock treatment. As shown in Fig. 6 islet cell $\mathrm{NAD}^{+}$levels dropped to $\sim 10 \%$ of normal following exposure to ROI, as rapidly as seen above for DNA strand breaks, with no recovery during the following hours. Heat shock treatment partly prevented the depletion of $\mathrm{NAD}^{+}$, the minimal

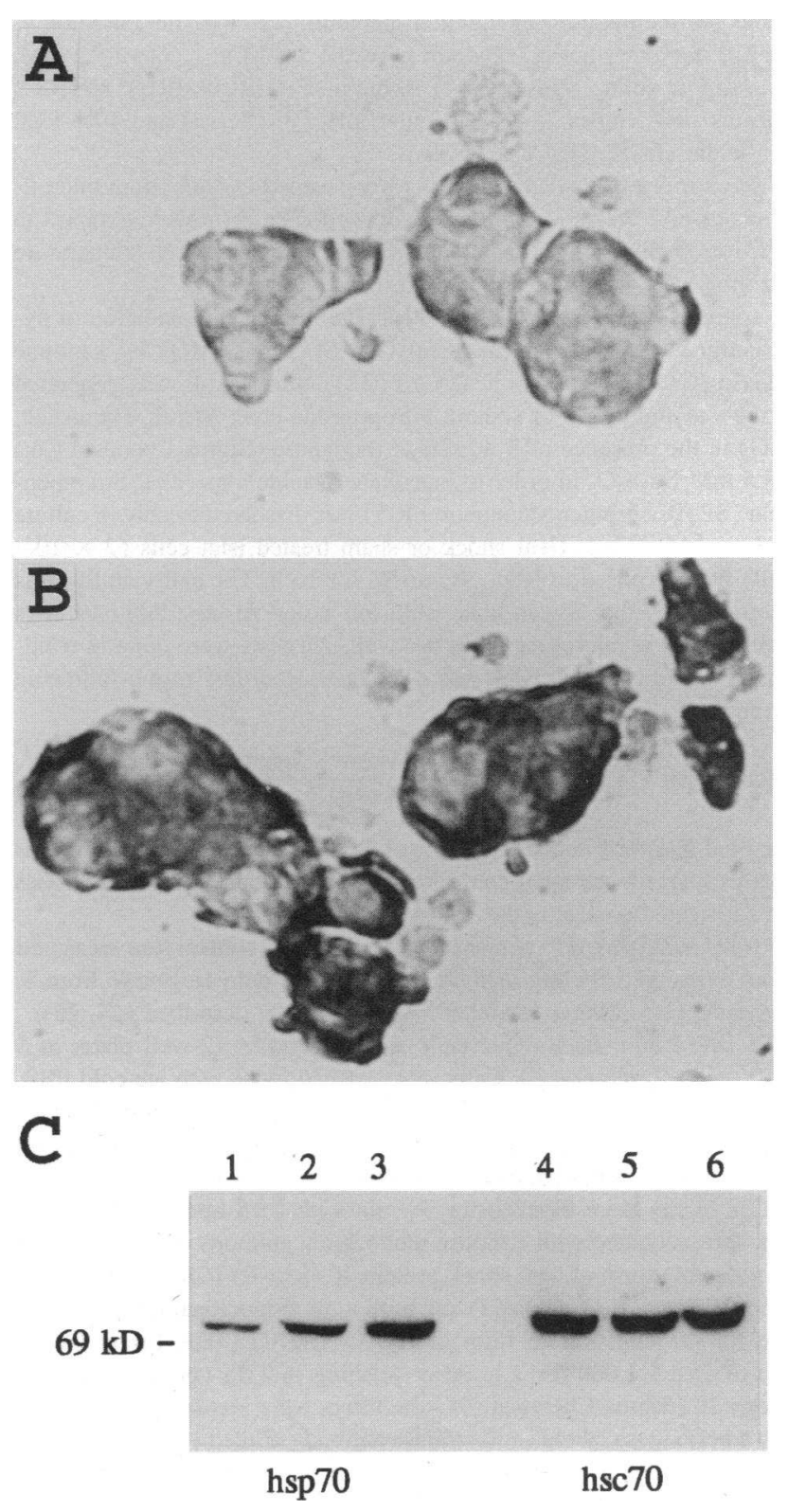

Figure 3. Induction of hsp70 expression by heat shock. Immunocytochemical staining of islet cells against hsp70. Islet cells were exposed to heat shock at $43^{\circ} \mathrm{C}$ for $90 \mathrm{~min}(B)$. Control cells $(A)$ and heatshocked cells were incubated with a monoclonal antibody directed against the inducible form of hsp70. Expression of hsp70 and hsc70 in islet cells $(C)$. Proteins of $5 \times 10^{5}$ lysed cells per lane were electrophoresed through $10 \%$ SDS-PAGE, blotted onto nitrocellulose and detected using monoclonal antibodies against hsp70 (lanes $1-3$ ) or hsc70 (lanes 4-6). Lanes 1 and 4 represent the control cells, the cells in lanes 2, 3, 5 , and 6 were heat shocked at $43^{\circ} \mathrm{C}$ for $90 \mathrm{~min}$ with a recovery period of $30 \mathrm{~min}$ (lanes 2 and 5 ) or $120 \mathrm{~min}$ (lanes 3 and 6 ) at $37^{\circ} \mathrm{C}$.

level being $60 \%$ of normal (Fig. 6). When NAD ${ }^{+}$consumption by PARP was directly inhibited by the drug 3-aminobenzamide intracellular $\mathrm{NAD}^{+}$levels were preserved to a similar degree as after heat shock (Fig. 6). The PARP inhibition by 3 -aminobenzamide also inhibited oxygen radical induced cell lysis which was reduced from $80.8 \pm 4.4 \%$ after $16 \mathrm{~h}$ to $11.7 \pm 2.9 \%$ ( $P \leq 0.001$ ) by $30 \mathrm{~min}$ pretreatment with $6 \mathrm{mM} \mathrm{3-aminobenz-}$ amide. To determine whether PARP activity was inhibited by 

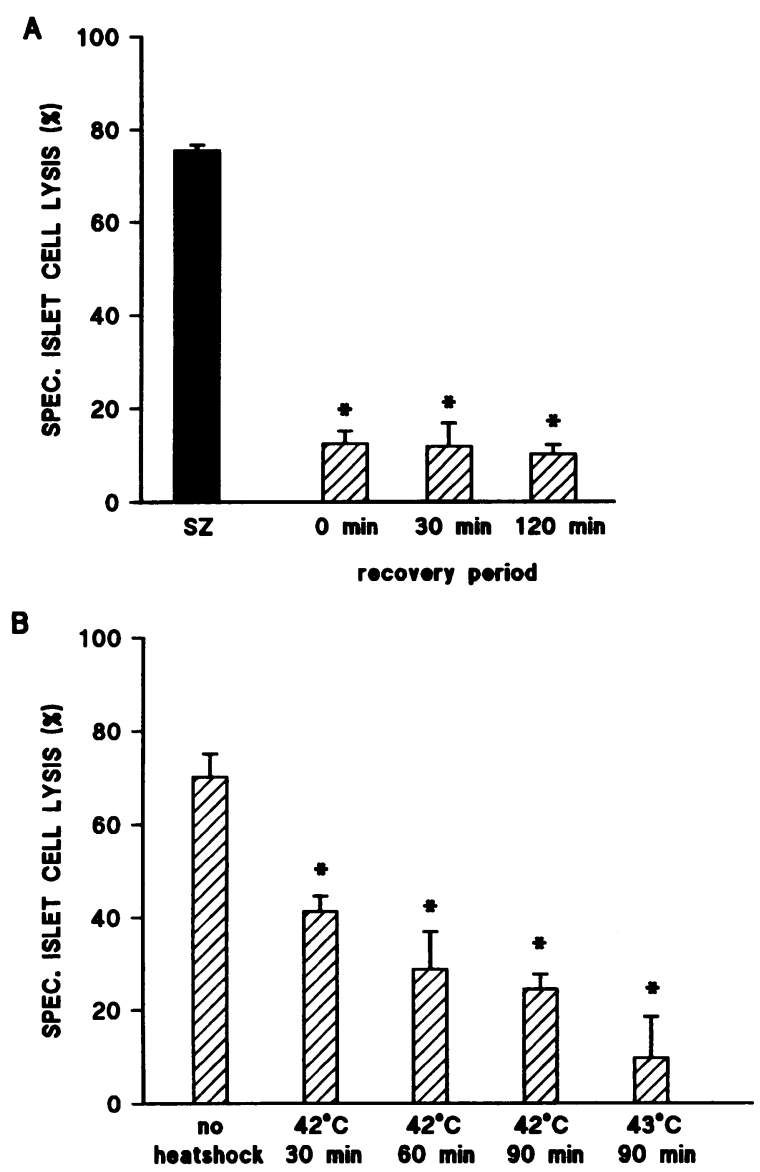

Figure 4. Kinetics of heat shock induced resistance. $(A)$ No effect of the duration of the recovery period after heat shock treatment on islet cell protection. Islet cells were exposed to $\mathrm{SZ}(1.5 \mathrm{mM})$ for $16 \mathrm{~h}$ after a heat shock treatment at $43^{\circ} \mathrm{C}$ for $90 \mathrm{~min}$. The recovery period between heat shock and addition of SZ was varied from 0 to $120 \mathrm{~min}$. Solid bars indicate the non heat shocked cells, hatched bars indicate the heat treated cells. Data represent means \pm SD of at least two experiments performed in triplicate, $P \leq 0.001$ ( $*$ ) compared with the non-heat shocked control. $(B)$ Variation of the heat shock conditions. Islet cells were exposed to different temperatures and duration of heat shock treatment. After a recovery period of $30 \mathrm{~min}$ the cells were exposed to $\mathrm{SZ}(1.0 \mathrm{mM})$. Solid bars indicate non heat shocked cells, hatched bars indicate cells treated with heat shock. Data represent means \pm SD of at least two experiments performed in triplicate, $P \leq 0.001(*)$ compared with the nonheat shocked control.

heat shock treatment the cells were permeabilized and the formation of ADP-ribosylation products determined by a standard radioactive assay (28). As shown in Fig. 7 exposure of islet cells to ROI induced strong ADP-ribosylation activity which was suppressed in the presence of the PARP inhibitor 3-aminobenzamide. Prior heat shock treatment caused a $70 \%$ reduction of ADP-ribosylation. This lesser consumption of $\mathrm{NAD}^{+}$is reflected by better preservation of intracellular $\mathrm{NAD}^{+}$levels in heat shocked islet cells (Fig. 6).

\section{Discussion}

The results of this study show that heat shock is a potent inducer of resistance in pancreatic islet cells against the cytotoxicity of NO, ROI, and SZ. Incubation with these cytotoxic agents leads

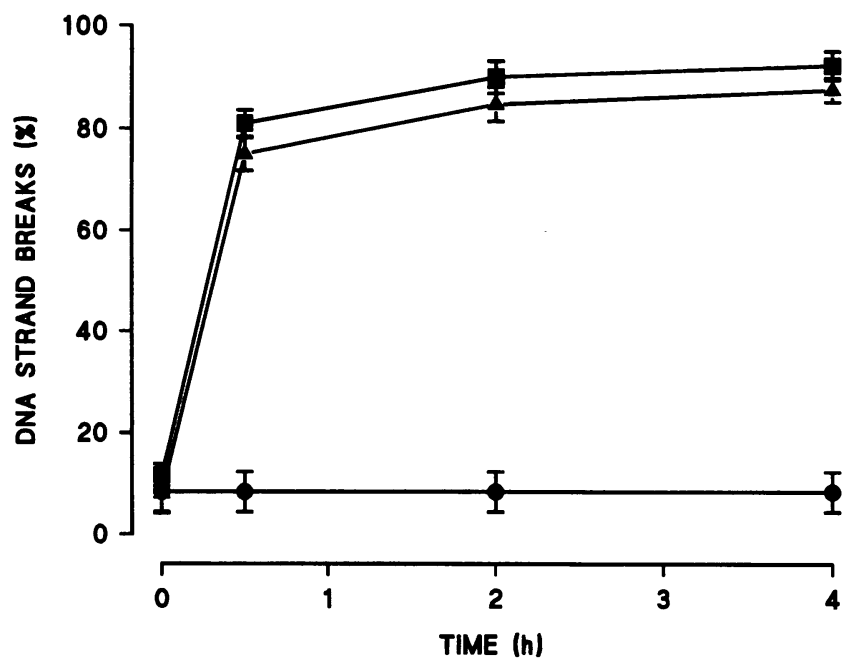

Figure 5. Effect of heat shock on time course of DNA strand breaks. Islet cells were exposed to ROI ( $12 \mathrm{mU}$ xanthine oxidase, $0.05 \mathrm{mM}$ hypoxanthine) without $(\Delta)$ and with $(\square)$ heat shock pretreatment at $43^{\circ} \mathrm{C}$ for $90 \mathrm{~min}$ (sham-treated control $\bullet$ ). DNA strand breaks were determined microscopically by in situ nick translation. Data represent means $\pm S D$ of at least four tests.

to severe damage in islet cells followed by cell death. This can be almost completely prevented by a heat shock treatment at $43^{\circ} \mathrm{C}$ for $90 \mathrm{~min}$. These observations demonstrate the existence of a stress protein-dependent defense mechanism in islet cells. Furthermore, we show for the first time that a heat shock response can confer resistance from NO toxicity. The most striking alteration in heat exposed cells is the increased expression of a selected group of proteins, the so-called heat shock proteins. In this study we focused on the expression of hsp70 which is most highly inducible in mammalian cells $(29,30)$ and was shown to be protective against oxygen radicals (17) and IL-1

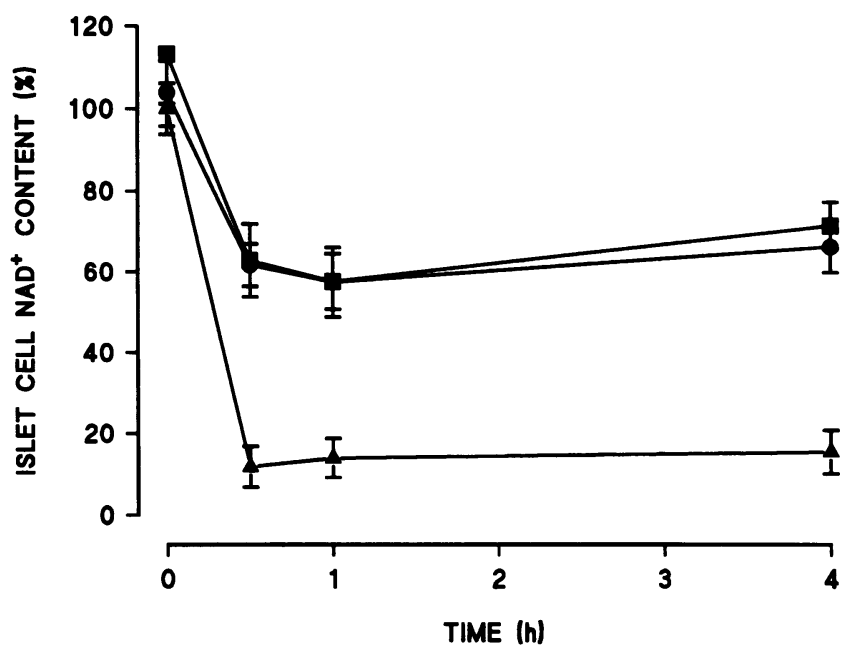

Figure 6. Effect of heat shock on $\mathrm{NAD}^{+}$levels. Islet cells were exposed to ROI ( $12 \mathrm{mU}$ xanthine oxidase, $0.05 \mathrm{mM}$ hypoxanthine) without ( $\Delta$ ) and with $(\square)$ heat shock pretreatment at $43^{\circ} \mathrm{C}$ for 90 min or with 3aminobenzamide $(6 \mathrm{mM})$ pretreatment $(\bullet) 30$ min before the exposure to ROI. Islet cell $\mathrm{NAD}^{+}$content at time point zero was set at $100 \%$ and corresponds to $0.413 \pm 0.028 \mathrm{pmol} / 10^{3}$ cells. Data represent means of at least four experiments. 


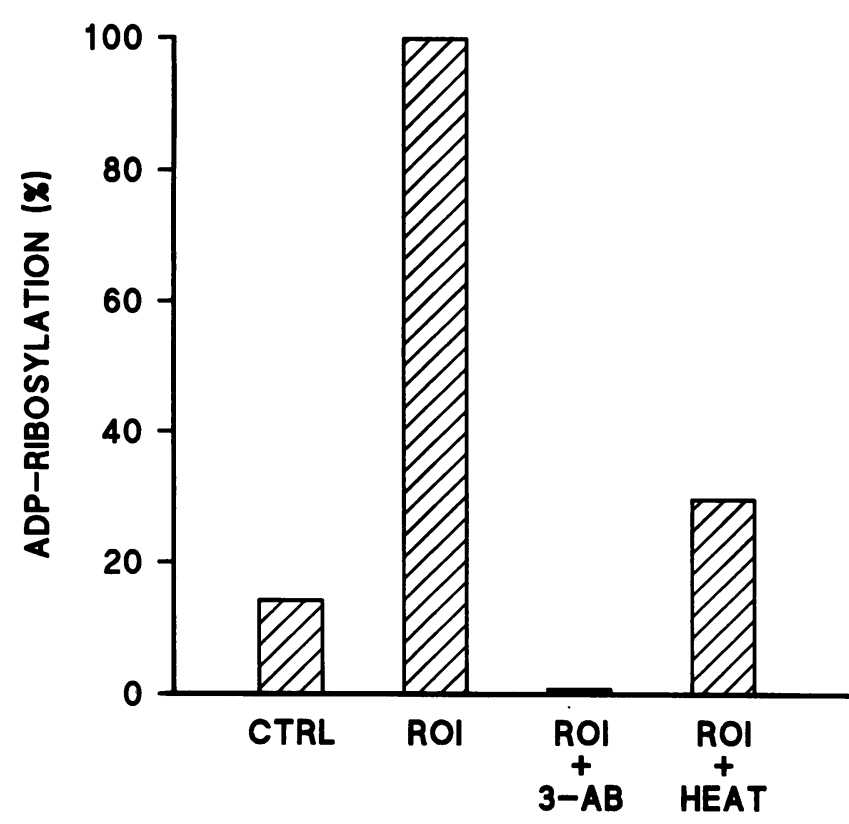

Figure 7. Effect on heat shock on ADP-ribosylation. Islet cells were exposed to ROI ( $12 \mathrm{mU}$ xanthine oxidase, $0.05 \mathrm{mM}$ hypoxanthine) for $10 \mathrm{~min}$ with or without prior heat shock treatment at $43^{\circ} \mathrm{C}$ for $90 \mathrm{~min}$. $C T R L$, sham-treated control cells; ROI, cells exposed to ROI for 10 $\mathrm{min} ; R O I+3-A B$, cells exposed to ROI in the presence of $6 \mathrm{mM} 3-$ aminobenzamide; $R O I+H E A T$, cells exposed to ROI after heat shock. Poly (ADP-ribose) synthesis after $10 \mathrm{~min}$ of exposure to ROI was set at $100 \%$ and corresponds to $402.9 \mathrm{cpm} / 1.25 \times 10^{5}$ cells. Data represent means of at least two experiments.

(16). By immunocytochemical staining and Western blot analysis we could prove that islet cells express the inducible form of hsp70 $30 \mathrm{~min}$ after the termination of heat shock treatment at $43^{\circ} \mathrm{C}$ for $90 \mathrm{~min}$. This is a very rapid reaction compared with other cell types (tissue culture cells) in which hsp70 could only be detected $2-4 \mathrm{~h}$ after heat shock (31-33). An earlier study showed that IL-1 induced hsp70 persists in islet cells for at least $24 \mathrm{~h}$ (19).

The protective effect of heat shock was observed immediately after the termination of the heat shock treatment. These findings indicate that islet cells have defence mechanisms against islet toxic compounds which are rapidly activated by heat shock. This conclusion is supported by recent studies of Freeman et al. (34) who demonstrated that hsp70 mRNA is elevated in cells with artificially reduced glutathione, a compound which is involved in reactive radical scavenging. Interestingly, islet cells were found to have a disturbed glutathione metabolism with a 10-fold lower glutathione peroxidase activity compared with other cell types (35). Therefore it may be suggested that islet cells are able to produce hsp70 more rapidly than other cells this way compensating their reduced radical scavenging potential. The deleterious effects of the toxins NO, SZ, and ROI was shown to depend mainly on their ability to induce DNA strand breaks thereby triggering a sequence of events leading to islet cell death $(22,36)$. A critical event after DNA damage is the activation of poly (ADP-ribose) polymerase (PARP) which causes a lethal depletion of the cellular NAD ${ }^{+}$ levels due to the formation of poly (ADP-ribose) at the sites of DNA strand breaks $(8,37)$. Recently, we were able to provide direct proof of this pathway of cell death by studying cells from animals with disrupted PARP gene. Consequently, we analyzed the appearance of DNA strand breaks and the $\mathrm{NAD}^{+}$levels in order to determine at which level the heat shock induced protection occurs in islet cells. Our results showed no protective effect of heat shock treatment on the initial induction of DNA damage. Thus, for survival of DNA-damaged cells heat shock treatment must have aborted the lethal sequel of PARP activation with concomitant $\mathrm{NAD}^{+}$depletion, ATP loss and plasma membrane lysis. Our findings show that heat shock interferes with the first step, the $\mathrm{NAD}^{+}$consumption by PARP. Preservation of NAD ${ }^{+}$ levels by heat shock was as pronounced as seen in the presence of a PARP inhibitor. Analysis of the ADP-ribosylation reaction in islet cells indeed showed suppression after heat shock treatment.

Presently, it is not known which hsp is responsible for preventing $\mathrm{NAD}^{+}$consumption by PARP and whether this involves binding of hsp to PARP or to DNA. A candidate protective protein is hsp70 because of its rapid induction in islet cells and because of two reports showing that the selective upregulation of hsp70 by transfection or by administration of hsp70 containing liposomes protects from TNF $\alpha$ or IL- 1 toxicity $(16,31)$. In favor of our assumption is a recent report showing that hsp70 also accumulates in the nucleus and forms complexes with nuclear topoisomerase I during heat stress (38). To resolve this issue transfection experiments with islet cells with the hsp70 gene are on the way.

The finding that a heat shock response confers resistance against NO as well as ROI indicates that islet cells may counterbalance their increased susceptibility towards NO and ROI (6, 39 ) by a rapid stress gene response, as shown here. Hence, heat shock protein expression during islet inflammation $(40,41)$ may be an important parameter determining the outcome of chronic insulitis with regard to beta cell survival. In this context it is of interest that alleles of the hsp70 gene in the MHC complex have been found associated with type 1 diabetes in man $(42,43)$. It may be worthwhile to identify ways of supporting the stress gene response of tissue under inflammatory attack. As shown here heat shock protection can be mimicked by inhibition of PARP. Administration of nicotinamide, an inhibitor of ADP-ribosylation, in vivo indeed has resulted in prevention of autoimmune beta cell destruction (44).

\section{Acknowledgments}

We thank Dr. M. Jäättelä of the Danish Cancer Society Research Center (Copenhagen, Denmark) for reading the manuscript.

This study was supported by the Bundesminister für Gesundheit, the Minister für Wissenschaft und Forschung des Landes NordrheinWestfalen, the Juvenile Diabetes Foundation International, the TraudlEnglhorn-Stifung and the Deutsche Diabetes-Gesellschaft.

\section{References}

1. Kolb, H., and V. Kolb-Bachofen. 1992. Type 1 (insulin-dependent) diabetes mellitus and nitric oxide. Diabetologia. 35:796-797.

2. Corbett, J. A., and M. L. McDaniel. 1992. Does nitric oxide mediate autoimmune destruction of B cells? Possible therapeutic interventions in IDDM. Diabetes. 41:897-903.

3. Southern, C., D. Schulster, and I. G. Green. 1990. Inhibition of insulin secretion by interleukin $1 \beta$ and tumour necrosis factor- $\alpha$ via an L-arginine-dependent nitric oxide generating mechanism. FEBS (Fed. Eur. Biochem. Soc.) Lett. 276:42-44.

4. Nerup, J., T. Mandrup-Poulsen, J. Mølvig, S. Helqvist, L. Wogensen, and J. Egeberg. 1988. Mechanism of pancreatic $\beta$-cell destruction in type I diabetes. Diabetes Care. [Suppl. 1] 11:16-23. 
5. Pipeleers, D., and M. Van De Winkel. 1986. Pancreatic B cells possess defense mechanisms against cell-specific toxicity. Proc. Natl. Acad. Sci USA. 83:5267-5271.

6. Kröncke, K.-D., H.-H. Brenner, M.-L. Rodriguez, E. Noack, H. Kolb, and V. Kolb-Bachofen. 1993. Pancreatic islet cells are highly susceptible towards the cytotoxic effects of chemically generated nitric oxide. Biochim. Biophys. Acta. 1182:221-229.

7. Grankvist, K., S. L. Marklund, and I.-B. Täljedal. 1981. CuZn-superoxide dismutase, Mn-superoxide dismutase, catalase and glutathione peroxidase in pancreatic islets and other tissues in the mouse. Biochem. J. 199:393-398.

8. Yamamoto, H., Y. Uchigata, and H. Okamoto. 1981. Streptozotocin and alloxan induce DNA strand breaks and poly (ADP-ribose) synthetase in pancreatic islets. Nature (Lond.). 294:284-286.

9. Rakieten, N., M. L. Rakieten, and M. V. Nadkarni. 1963. Studies on the diabetogenic action of streptozotocin (NSC-37917). Cancer Chemother. Rep. 29:91-97.

10. Uchigata, Y., H. Yamamoto, A. Kawamura, and H. Okamoto. 1982. Protection by superoxide dismutase, catalase, and poly (ADP-ribose) synthetase in hibitors against alloxan- and streptozotocin-induced islet DNA strand breaks and against the inhibition of proinsulin synthesis. J. Biol. Chem. 257:6084-6088.

11. Turk, J., J. A. Corbett, S. Ramanadham, A. Bohrer, and M. L. McDaniel. 1993. Biochemical evidence for nitric oxide formation from streptozotocin in isolated pancreatic islets. Biochem. Biophys. Res. Commun. 197:1458-1464.

12. Radons, J., B. Heller, A. Bürkle, B. Hartmann, M.-L. Rodriguez, K.-D. Kröncke, V. Burkart, and H. Kolb. 1994. Nitric oxide toxicity in islet cells involves poly (ADP-ribose) polymerase activation and concomitant NAD depletion. Biochem. Biophys. Res. Commun. 199:1270-1277.

13. Radons, J., E. Fengler, A. Bürkle, B. Heller, V. Burkart, and H. Kolb. 1993. Oxygen radicals induce ADP-ribose polymerization and NAD-depletion in isolated pancreatic islet cells. Diabetologia. (Suppl. 1) 36:1270-1277.

14. Heller, B., A. Bürkle, J. Radons, E. Fengler, A. Jalowy, M. Müller, V. Burkart, and H. Kolb. 1994. Analysis of oxygen radical toxicity in pancreatic islets at the single cell level. Biol. Chem. Hoppe-Seyler. 375:597-602.

15. Appels, B., V. Burkart, G. Kantwerk-Funke, J. Funda, V. Kolb-Bachofen, and H. Kolb. 1989. Spontaneous cytotoxicity of macrophages against pancreatic islet cells. J. Immunol. 142:3803-3808.

16. Margulis, B. A., S. Sandler, D. L. Eizirik, N. Welsh, and M. Welsh. 1991 Liposomal delivery of purified heat shock protein hsp70 into rat pancreatic islets as protection against interleukin $1 \beta$-induced impaired $\beta$-cell function. Diabetes. 40:1418-1422.

17. Jäättelä, M., and D. Wissing. 1993. Heat-shock proteins protect cells from monocyte cytotoxicity: possible mechanism of self protection. J. Exp. Med. 177:231-236.

18. Hunt, C. and R. I. Morimoto. 1985. Conserved features of eucaryotic hsp70 genes revealed by comparison with the nucleotide sequence of human hsp70. Proc. Natl. Acad. Sci. USA. 82:6455-6459.

19. Helqvist, S., B. S. Polla, J. Johannesen, and J. Nerup. 1991. Heat shock protein induction in rat pancreatic islets by recombinant human interleukin $1 \beta$. Diabetologia. 34:150-156.

20. Craig, E. A. 1991. The heat shock response. CRC Crit. Rev. Biochem. 18:239-279.

21. Milarski, K. L., W. J. Welch, and R. I. Morimoto. 1989. Cell cycledependent association of hsp70 with specific cellular proteins. J. Cell Biol. 108:413-423.

22. Burkart, V., T. Koike, H.-H. Brenner, and H. Kolb. 1992. Oxygen radicals generated by the enzyme xanthine oxidase lyse rat pancreatic islet cells in vitro. Diabetologia. 35:1028-1034.

23. Kallmann, B., V. Burkart, K.-D. Kröncke, V. Kolb-Bachofen, and H. Kolb. 1992. Toxicity of chemically generated nitric oxide towards pancreatic islet cells can be prevented by nicotinamide. Life Sciences. 51:671-678.
24. Nisselbaum, J. S., and S. Green. 1969. A simple ultramicro method for determination of pyridine nucleotides in tissues. Anal. Biochem. 27:212-217.

25. Hinz, M., N. Katsilambros, V. Maier, H. Schatz, and E. F. Pfeiffer. Significance of streptozotocin induced nicotinamid-adenine-dinucleotide $\left(\mathrm{NAD}^{+}\right)$ degradation in mouse pancreatic islets. 1973. FEBS (Fed. Eur. Biochem. Soc.) Lett. 30:225-228.

26. Laemmli, U. K. 1970. Cleavage of structural proteins during the assembly of the head of bacteriophage T4. Nature (Lond). 227:680-685.

27. Fehsel, K., V. Kolb-Bachofen, and H. Kolb. 1991. Analysis of TNF $\alpha$ induced DNA strand breaks at the single cell level. Am. J. Pathol. 139:251-254.

28. Grube, K., J.-H. Küpper, and A. Bürkle. 1991. Direct stimulation of Poly (ADP ribose) polymerase in permeabilized cells by double-stranded DNA oligomers. Anal. Biochem. 193:236-239.

29. Welch, J. W. 1992. Mammalian stress response: cell physiology, structure/ function of stress proteins, and implications for medecine and disease. Physiological Reviews. 72:1063-1081.

30. Jäättelä, M., and D. Wissing. 1992. Emerging role of heat shock proteins in biology and medicine. Anal. Med. 27:249-258.

31. Jäättelä, M., and D. Wissing. 1993. Heat shock proteins protect cells from monocyte toxicity: possible mechanism of self-protection. J. Exp. Med. 177:231 236.

32. Steels, E. L., K. Watson, and P. G. Parsons. 1992. Relationships between thermotolerance, oxidative stress responses and induction of stress proteins in human tumour cell lines. Biochem. Pharmacol. 44:2123-2129.

33. Welch, J. W., and J. P. Suhan. 1986. Cellular and biochemical events in mammalian cells during and after recovery from physiological stress. J. Cell Biol. 103:2035-2052.

34. Freeman, M. L., E. Sierra-Riviera, G. J. Voorhees, D. R. Eisert, and M. L. Meredith. 1993. Synthesis of hsp70 is enhanced in glutathione depleted Hep G2 cells. Radiat. Res. 135:387-393.

35. Malaisse, W. J., F. Malaisse-Lagae, A. Sener, and D. G. Pipeleers. 1982. Determinants of the selective toxicity of alloxan to the pancreatic B cell. Proc. Natl. Acad. Sci. USA. 79:927-930.

36. Carson, D. A., S. Seto, and D. B. Wasson. 1986. Lymphocyte dysfunction after DNA damage by toxic oxygen species. J. Exp. Med. 163:746-751.

37. Schraufstatter I. U., P. A. Hyslop, D. B. Hinshaw, R. G. Spragg, L. A Sklar, and C. G. Cochrane. 1986. Hydrogen peroxide-induced injury of cells and its prevention by inhibitors of poly (ADP-ribose) polymerase. Proc. Natl. Acad. Sci. USA. 83:4908-4912.

38. Ciavarra, R. P., C. Goldman, K-K. Wen, B. Tedeschi, and F. J. Castora 1994. Heat stress induces hsc70/nuclear topoisomerase I complex formation in vivo: Evidence for hsc70-mediated, ATP-independent reactivation in vitro. Proc Natl. Acad. Sci. USA. 91:1751-1755.

39. Rabinovitch, A. 1992. Free radicals as mediators of pancreatic islet $\beta$-cell injury in autoimmune diabetes. J. Lab. Clin. Med. 119:455-456.

40. Brudzynski, K., V. Martinez, and R. S. Gupta. 1992. Immunochemical localization of heat-shock protein 60-related protein in Beta-cell secretory granules and its altered distribution in non-obese diabetic mice. Diabetologia. 35:316324.

41. Brudzynski, K. 1993. Insulitis-caused redistribution of heat-shock protein hsp60 inside $\beta$-cells correlates with induction of hsp60 autoantibodies. Diabetes. 42:908-913.

42. Pugliese, A., Z. L. Awdeh, A. Galluzzo, E. J. Yunis, C. A. Alper, and G. S. Eisenbarth. 1992. No independent association between hsp70 genepolymorphism and IDDM. Diabetes. 41:788-791.

43. Leung, P. S., and M. E. Gershwin. 1991. The immunobiology of heat shock proteins. J. Invest. Allergol. \& Clin. Immunol. 1:23-30.

44. Yamada, K., K. Nonaka, T. Hanafusa, A. Miyazaki, H. Toyoshima, and S. Tarui. 1982. Preventive and therapeutic effects of large-dose nicotinamide injections on diabetes associated with insulitis. Diabetes. 31:749-753. 